\title{
Thermoanaerobacter yonseiensis sp. nov., a novel extremely thermophilic, xylose-utilizing bacterium that grows at up to $85^{\circ} \mathrm{C}$
}

\footnotetext{
1 Department of Biotechnology and Bioproducts Research Center, Yonsei University, Seodaemungu Shinchondong 134, Seoul 120-749, Korea

2 Institute of Technical Microbiology, Technical University HamburgHarburg, Denickestrasse 15, D-21073 Hamburg, Germany
}

\author{
Byoung-Chan Kim, ${ }^{1}$ Ralf Grote, ${ }^{2}$ Dong-Woo Lee, ${ }^{1}$ Garabed Antranikian ${ }^{2}$ \\ and Yu-Ryang Pyun ${ }^{1}$
}

Author for correspondence: Yu-Ryang Pyun. Tel: +82 2361 2883. Fax: +82 23126821. e-mail:yrpyun@yonsei.ac.kr

A novel strictly anaerobic, extremely thermophilic, spore-forming and xyloseutilizing bacterium, designated strain KB-1 ${ }^{\text {TP }}$ (type and patent strain), was isolated from a geothermal hot stream at Sileri on Java island, Indonesia. The cells were rod-shaped, motile and had terminal spores. The newly isolated strain stained Gram-positive and the cells occurred singly or in pairs during the exponential growth phase. The temperature optimum for growth was $75^{\circ} \mathrm{C}$ and growth occurred in the range $50-85^{\circ} \mathrm{C}$. The $\mathrm{pH}$ range for growth was 4.5-9.0, with an optimum at pH 6.5. Strain KB-1 ${ }^{\mathrm{TP}}$ grew chemo-organotrophically by fermenting a wide range of substrates such as glucose, fructose, D-xylose, lactose, maltose, sucrose, mannose, galactose, cellobiose, pullulan and soluble starch. Arabinose, xylan, cellulose, olive oil and Tween $\mathbf{8 0}$ were not fermented. The predominant fermentation end products after growth on glucose were lactate, acetate, ethanol, $\mathrm{CO}_{2}$ and small amounts of isovaleric acid, butyric acid, propionic acid, 1-pentanol and 2-propanol. Thiosulfate was reduced to $\mathrm{H}_{2} \mathrm{~S}$. Strain KB-1 ${ }^{\mathrm{TP}}$ was sensitive to tetracycline, chloramphenicol, penicillin $\mathrm{G}$, neomycin, kanamycin, vancomycin and rifampicin at concentrations of $100 \mu \mathrm{g}$ $\mathrm{ml}^{-1}$. No effect was observed with chloramphenicol and neomycin at concentrations of $10 \mu \mathrm{g} \mathrm{ml}^{-1}$. This indicates that strain KB-1 ${ }^{\mathrm{TP}}$ belongs to the bacterial domain. The $G+C$ content of the DNA was $37 \mathrm{~mol} \%$. The comparison of the 16S rDNA sequence to that of closely related strains revealed that strain KB-1 ${ }^{\text {TP }}$ belonged to clostridial cluster $V$, showing highest sequence identities $(92.7 \%)$ to members of the genus Thermoanaerobacter. Taking into account the physiological and molecular properties of the new isolate, it is proposed that strain KB-1 ${ }^{\mathrm{TP}}$ should be classified as a new species of the genus Thermoanaerobacter, designated Thermoanaerobacter yonseiensis. The type strain, KB-1 ${ }^{\mathrm{TP}}$, has been deposited in the Korean Federation of Culture Collections (KFCC 11116) as a patent strain and in the Deutsche Sammlung von Mikroorganismen und Zellkulturen as a type strain (= DSM 13777').

Keywords: Thermoanaerobacter yonseiensis, thermophiles

\section{INTRODUCTION}

In the last two decades, our understanding of the biology of thermophilic and other extremophilic micro-organisms has been greatly advanced. Thermophiles, which are found in both the bacterial and the archaeal domains, have been detected in association

The GenBank accession number for the 16S rDNA sequence of Thermoanaerobacter yonseiensis strain $\mathrm{KB}-1^{\mathrm{TP}}$ is AF212925. with all types of thermal habitats, including hot springs, volcanoes, solfataric fields and deep-sea hydrothermal vents (Stetter, 1996). Due to the biotechnological potential of anaerobic microbes, many research groups have focused on the thermophilic anaerobes that are able to utilize monomeric and polymeric carbohydrates. Many thermophilic, anaerobic and saccharolytic bacteria were first described as members of Clostridium and Desulfotomaculum, but were later transferred to the genera Thermo- 
anaerobacterium and Thermoanaerobacter (Lee et al., 1993a). As molecular biological techniques such as $16 \mathrm{~S}$ rDNA sequencing and DNA-DNA hybridization have improved, the taxonomic and phylogenetic relationships of these thermophilic genera have been further defined by Lee et al. (1993a) and Rainey et al. (1993). The genus Thermoanaerobacter falls into cluster A of thermophiles as defined by Rainey et al. (1993) and currently comprises 12 species, namely Thermoanaerobacter brockii (formerly Thermoanaerobium brockii; now including the three subspecies, brockii, finnii and lactiethylicus; Zeikus et al., 1979; Cayol et al., 1995), Thermoanaerobacter mathranii (Larsen et al., 1997), Thermoanaerobacter italicus (Kozianowski et al., 1997), Thermoanaerobacter wiegelii (Cook et al., 1996), Thermoanaerobacter acetoethylicus (formerly Thermobacteroides acetoethylicus; Ben-Bassat \& Zeikus, 1981; Rainey \& Stackebrandt, 1993; Collins et al., 1994), Thermoanaerobacter ethanolicus (Wiegel \& Ljungdahl, 1981), Thermoanaerobacter thermocopriae (formerly Clostridium thermocopriae; Jin et al., 1988), Thermoanaerobacter sulfurophilus (BonchOsmolovskaya et al., 1997), Thermoanaerobacter thermohydrosulfuricus (formerly Clostridium thermohydrosulfuricum; Wiegel et al., 1979; Lee et al., 1993a), Thermoanaerobacter kivui (formerly Acetogenium kivui; Leigh et al., 1981; Collins et al., 1994), Thermoanaerobacter siderophilus (Slobodkin et al., 1999) and Thermoanaerobacter subterraneus (Fardeau et al., 2000). In general, members of the genus Thermoanaerobacter are thermophilic and rod-shaped anaerobes that grow chemo-organotrophically on a variety of saccharides as energy and carbon source, forming mainly ethanol, acetate and lactate as fermentation end products (Lee et al., 1993a). Thermoanaerobacter kivui is the only homoacetogen in this genus, but it clearly does not belong to other genera that contain thermophilic homoacetogenic organisms, e.g. Moorella thermoacetica (formerly Clostridium thermoaceticum) and Moorella thermoautotrophica (formerly Clostridium thermoautotrophicum) (Collins et al., 1994). The majority of Thermoanaerobacter species were found to be sporulating organisms. However, lack of spore formation may only be the result of the inability of the taxonomist to provide conditions to induce sporulation, as was found in the case of Thermoanaerobacter brockii (Cook et al., 1991). The Gram-reaction is negative, positive or variable. In contrast to the report of Lee et al. (1993a), some species of the genus Thermoanaerobacter also accumulate elemental sulfur at the same time as they reduce thiosulfate to $\mathrm{H}_{2} \mathrm{~S}$ (Kozianowski et al., 1997).

Much attention has been paid to xylose-utilizing extreme thermophiles or hyperthermophiles since these micro-organisms are a promising source of thermostable and thermoactive D-xylose isomerases. These enzymes are of great interest for the production of high-fructose corn syrup (HFCS) in the starch processing industry (Brown et al., 1993; Dekker et al., 1991a, b; Liu et al., 1996). Only a limited number of extreme thermophilic micro-organisms are able to utilize xylose. Thermostable and thermoactive Dxylose (D-glucose) isomerases have been characterized from members of the genera Thermus (Dekker et al., 1991a; Park et al., 1997), Thermotoga (Brown et al., 1993; Vielle et al., 1995), Thermoanaerobacterium (Lee et al., 1993b; Meaden et al., 1994; Liu et al., 1996) and Thermoanaerobacter (Erbeznik et al., 1998; Dekker et al., 1991b). Except for some Thermus and Thermotoga strains, the majority of these bacteria is unable to grow above $80^{\circ} \mathrm{C}$ with xylose as sole carbon source.

In this paper we report on the isolation and characterization of the xylose-utilizing strain $\mathrm{KB}-1^{\mathrm{TP}}$ that grows up to $85^{\circ} \mathrm{C}$. Based on morphological, physiological and phylogenetic studies, it is concluded that this extremely thermophilic isolate is a new species of the genus Thermoanaerobacter for which the name Thermoanaerobacter yonseiensis is proposed.

\section{METHODS}

Reference strains. Thermococcus siculi DSM $12349^{\mathrm{T}}$, Thermotoga maritima DSM $3109^{\mathrm{T}}$, Thermoanaerobacter brockii subsp. brockii DSM $1457^{\mathrm{T}}$ and Thermoanaerobacter ethanolicus DSM $2246^{\mathrm{T}}$ were purchased from the Deutsche Sammlung von Mikroorganismen und Zellkulturen (DSMZ), Braunschweig, Germany.

Origin of the isolate. Samples of hot water, mud and soil were collected from hot streams at Sileri (Java island) associated with volcanic activity in Indonesia. The samples were transported in sterile plastic bottles at ambient temperature. Each collection bottle was completely filled and supplemented with $\mathrm{Na}_{2} \mathrm{~S} .9 \mathrm{H}_{2} \mathrm{O}$ as reducing agent at a final concentration of $0.5 \mathrm{~g}^{-1}$. The in situ temperature of the streams was between 60 and $80^{\circ} \mathrm{C}$, and the collected samples had a $\mathrm{pH}$ range of $4 \cdot 0-7 \cdot 0$.

Culture conditions. An enrichment culture medium (EMKB1 medium) for strictly anaerobic thermophiles was designed and contained the following components (per litre distilled water): $2.0 \mathrm{~g} \mathrm{NaCl}, 0.5 \mathrm{~g} \mathrm{KH}_{2} \mathrm{PO}_{4}, 0.1 \mathrm{~g} \mathrm{~K}_{2} \mathrm{HPO}_{4}$,

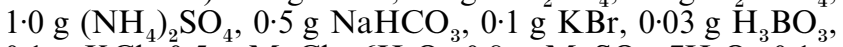
$0.1 \mathrm{~g} \mathrm{KCl}, 0.5 \mathrm{~g} \mathrm{MgCl}_{2} .6 \mathrm{H}_{2} \mathrm{O}, 0 \cdot 8 \mathrm{~g} \mathrm{MgSO}_{4} .7 \mathrm{H}_{2} \mathrm{O}, 0 \cdot 1 \mathrm{~g}$ $\mathrm{CaCl}_{2} \cdot 2 \mathrm{H}_{2} \mathrm{O}, 0.03 \mathrm{~g} \mathrm{SrCl}_{2} \cdot 6 \mathrm{H}_{2} \mathrm{O}, 0.033 \mathrm{mg} \mathrm{Na}_{2} \mathrm{WO}_{4}$, $0.026 \mathrm{mg} \mathrm{Na} 2 \mathrm{SeO}_{3}, 10 \mathrm{ml}$ trace element solution (Balch $e t$ al., 1979), $10 \mathrm{ml}$ vitamin solution (Wolin et al., 1964), $1.0 \mathrm{~g}$ yeast extract, $10 \mathrm{~g}$ elemental sulfur, $1 \mathrm{mg}$ resazurin and $3 \mathrm{ml}$ $\mathrm{Na}_{2} \mathrm{~S} .9 \mathrm{H}_{2} \mathrm{O}(25 \%$ solution, w/v, $\mathrm{pH} 8 \cdot 0)$. To this medium, filter-sterilized solutions of xylose, tryptone, starch or pyruvate (final concentration $5 \cdot 0 \mathrm{~g} \mathrm{l}^{-1}$ ) were added. Growth medium GM-KB1 contained (per litre distilled water): $2.0 \mathrm{~g} \mathrm{NaCl}, 0.1 \mathrm{~g} \mathrm{KCl}, 0.2 \mathrm{~g} \mathrm{NaHCO}_{3}, 0.5 \mathrm{~g} \mathrm{KH}_{2} \mathrm{PO}_{4}, 0.5 \mathrm{~g}$ $\left(\mathrm{NH}_{4}\right)_{2} \mathrm{SO}_{4}, 0.1 \mathrm{~g} \mathrm{KBr}, 0.03 \mathrm{~g} \mathrm{H}_{3} \mathrm{BO}_{3}, 0.5 \mathrm{~g} \mathrm{MgCl}_{2} .6 \mathrm{H}_{2} \mathrm{O}$, $0.5 \mathrm{~g} \mathrm{MgSO}_{4} \cdot 7 \mathrm{H}_{2} \mathrm{O}, 0.5 \mathrm{~g} \mathrm{CaCl}_{2} .2 \mathrm{H}_{2} \mathrm{O}, 0.03 \mathrm{~g} \mathrm{SrCl}_{2} \cdot 6 \mathrm{H}_{2} \mathrm{O}$, $0.033 \mathrm{mg} \mathrm{Na}{ }_{2} \mathrm{WO}_{4}, 0.026 \mathrm{mg} \mathrm{Na} 2 \mathrm{SeO}_{3}, 10 \mathrm{ml}$ trace element solution (Balch et al., 1979), $10 \mathrm{ml}$ vitamin solution (Wolin et al., 1964), $5.0 \mathrm{~g}$ carbon source (separately sterilized), $1.0 \mathrm{~g}$ yeast extract, $2 \cdot 0 \mathrm{~g} \mathrm{Na}_{2} \mathrm{~S}_{2} \mathrm{O}_{3} .5 \mathrm{H}_{2} \mathrm{O}, 1 \mathrm{mg}$ resazurin and $3 \mathrm{ml}$ $\mathrm{Na}_{2} \mathrm{~S} .9 \mathrm{H}_{2} \mathrm{O}(25 \%$ solution, w/v, $\mathrm{pH} 8 \cdot 0)$. Both media were prepared without $\mathrm{Na}_{2} \mathrm{~S}$, boiled for 20 min and cooled down on ice under a $\mathrm{N}_{2}$ atmosphere. The media were finally reduced by the addition of $3 \mathrm{ml} \mathrm{Na}_{2} \mathrm{~S} .9 \mathrm{H}_{2} \mathrm{O}$ solution $(25 \%$ solution, w/v, pH 8.0). Sodium thiosulfate was filtersterilized and added separately after autoclaving. Unless otherwise stated, the media were adjusted to $\mathrm{pH} 6.5$ with 
$6 \mathrm{M} \mathrm{HCl}$ and dispensed into appropriate glass containers sealed with butyl-rubber stoppers under a $\mathrm{N}_{2}$ atmosphere. Sterilization of the media was performed by autoclaving at $121{ }^{\circ} \mathrm{C}$ for $20 \mathrm{~min}$ or at $100^{\circ} \mathrm{C}$ for $1 \mathrm{~h}$ if the medium contained elemental sulfur. Unless otherwise indicated, cultures were incubated under atmospheric pressure at $75^{\circ} \mathrm{C}$. All chemicals were purchased from Merck, except yeast extract and tryptone, which were obtained from Difco Laboratories.

Enrichment and isolation. Enrichment cultures (10\% inoculum, v/v) were grown on EM-KB1 medium at temperatures between 70 and $100^{\circ} \mathrm{C}$ and at $\mathrm{pH}$ values between $5 \cdot 0$ and $7 \cdot 0$ for several days. Isolates were obtained by successively growing end point dilutions at $80{ }^{\circ} \mathrm{C}$ and $\mathrm{pH} 6.5$ in medium EM-KB1, followed by spreading on $2.0 \%$ $(\mathrm{w} / \mathrm{v})$ agar-solidified EM-KB1 medium in Hungate tubes. Purified isolates were stored in liquid culture at $4{ }^{\circ} \mathrm{C}$ and could be used as inocula for at least 12 months. For longterm storage pure cultures were stored under anaerobic conditions in the presence of $50 \%(\mathrm{w} / \mathrm{v})$ glycerol at $-20^{\circ} \mathrm{C}$.

Determination of growth parameters. Microbial growth was either monitored by direct cell counting using a PetroffHausser chamber (depth $0.02 \mathrm{~mm}$ ) and phase-contrast microscopy at a magnification of $\times 400$, or by measuring the optical density in a spectrophotometer at $600 \mathrm{~nm}$. To determine the optimum temperature, cells were grown in serum bottles containing $50 \mathrm{ml}$ GM-KB1 medium supplemented with soluble starch $\left(5.0 \mathrm{~g} \mathrm{l}^{-1}\right)$ at $\mathrm{pH} \mathrm{7.0.} \mathrm{Deter-}$ mination of the optimum $\mathrm{pH}$ was performed at $75^{\circ} \mathrm{C}$. $\mathrm{KH}_{2} \mathrm{PO}_{4}$ and $\mathrm{NaHCO}_{3}$ were omitted from the GM-KB1 medium and $\mathrm{CaCl}_{2}$ was reduced to a final concentration of $0.05 \mathrm{~g} \mathrm{l}^{-1}$ to prevent precipitation. Additionally, the following filter-sterilized components (at a final concentration of $10 \mathrm{mM}$, except glucose) were added to GM-KB1 medium: glucose $\left(5 \cdot 0 \mathrm{~g} \mathrm{l}^{-1}\right)$; trisodium citrate, $\mathrm{pH}$ range $3 \cdot 0-5 \cdot 5$; MES sodium salt, $\mathrm{pH}$ range 5.5-6.5; Tris (trizma base), $\mathrm{pH}$ range 6.5-7.5; and $\mathrm{Na}_{2} \mathrm{CO}_{3}$, pH range 7.5-9.5. Elemental sulfur was used as electron acceptor instead of sodium thiosulfate in the acidic medium which contained trisodium citrate ( $\mathrm{pH} 4 \cdot 0-5 \cdot 5)$ to prevent precipitation. To monitor growth, samples (in duplicate) were withdrawn every hour. Utilization of various substrates as energy and carbon source was tested in a modified GM-KB1 medium with a reduced amount of yeast extract $\left(0 \cdot 1 \mathrm{~g} \mathrm{l}^{-1}\right)$. Unless otherwise indicated, the carbon sources were tested at a concentration of $5 \cdot 0 \mathrm{~g} \mathrm{l}^{-1}$. Cultures containing no additional carbon source served as control. The ability of the isolate to grow in the presence of various electron acceptors was determined in thiosulfate-free GM-KB1 medium supplemented with elemental sulfur $\left(10 \cdot 0 \mathrm{~g} \mathrm{l}^{-1}\right)$, L-cystine $\left(2 \cdot 0 \mathrm{~g} \mathrm{l}^{-1}\right)$, sodium thiosulfate $\left(2 \cdot 0 \mathrm{~g} \mathrm{l}^{-1}\right)$, sodium nitrate $\left(2 \cdot 0 \mathrm{~g} \mathrm{l}^{-1}\right)$ or sodium sulfite $\left(2 \cdot 0 \mathrm{~g} \mathrm{l}^{-1}\right)$. To determine the requirement of sodium thiosulfate as electron acceptor, microbial growth was monitored by direct cell counting using a Petroff-Hausser chamber after full growth $\left(70^{\circ} \mathrm{C}, 18 \mathrm{~h}\right)$ of the examined strains $(1 \%$ inoculum, v/v) in both GM-KB1 medium and thiosulfate-free GM-KB1 medium. Unless otherwise noted, the growth experiments were performed at least in duplicate.

Physiological tests and determination of fermentation products. Hucker's method (Brock \& Madigan, 1988) was applied for Gram-staining. The reduction of thiosulfate to $\mathrm{H}_{2} \mathrm{~S}$ was tested by the addition of $0 \cdot 2 \mathrm{~g} \mathrm{FeSO}_{4} \cdot 7 \mathrm{H}_{2} \mathrm{O}^{-1}$ to late exponential-phase cultures grown on medium GM-KB1 supplemented with $5.0 \mathrm{~g}$ glucose $1^{-1}$ and $2.0 \mathrm{~g}$ sodium thiosulfate $1^{-1}$. Blackening of the medium indicated the formation of $\mathrm{H}_{2} \mathrm{~S}$ (Jander \& Blasius, 1995). Uninoculated medium treated identically served as control. The formation of $\mathrm{CO}_{2}$ was monitored by barium carbonate precipitation as described by Jander \& Blasius (1995). Susceptibility of the new isolate to antibiotics was tested under standard growth conditions at $70^{\circ} \mathrm{C}$. The bacterium Thermotoga maritima DSM $3109^{\mathrm{T}}$ and the archaeon Thermococcus siculi DSM $12349^{\mathrm{T}}$ were used as controls to ensure the effectiveness of the antibiotics at elevated temperatures. Inhibition was defined by cell densities of less than $1 \times 10^{7}$ cells $\mathrm{ml}^{-1}$ in cultures containing antibiotics. Volatile fatty acids and alcohols were analysed by flame-ionization detection (FID) using a model Sigma 2000 gas chromatograph (Perkin Elmer). Lactate was determined enzymologically in a YSI model 2700 SELECT Biochemistry analyser as recommended by the manufacturer.

Electron microscopy. Cells were harvested by centrifugation at $5000 \mathrm{~g}$ for $10 \mathrm{~min}$ to prepare specimens for transmission electron microscopy and then fixed overnight in a solution containing $2.5 \%(\mathrm{w} / \mathrm{v})$ glutaraldehyde in $0.1 \mathrm{M}$ $\mathrm{Na}_{2} \mathrm{HPO}_{4} / \mathrm{KH}_{2} \mathrm{PO}_{4}\left(\mathrm{pH} 7 \cdot 2\right.$ ) buffer at $4{ }^{\circ} \mathrm{C}$, and post-fixed with $1 \%$ osmium tetroxide $\left(\mathrm{OsO}_{4}\right)$. Samples were then dehydrated with ethanol and embedded in Spurr. The sections were stained with $1 \%(\mathrm{w} / \mathrm{v})$ uranyl acetate and $1 \%$ $(\mathrm{w} / \mathrm{v})$ citrate and examined with a Philips model CM-10 electron microscope at an accelerating voltage of $80 \mathrm{kV}$. For scanning electron microscopy, cells were collected on a $0.4 \mu \mathrm{m}$ pore size Millipore HA filter and fixed with $2.5 \%$ (v/v) glutaraldehyde in $50 \mathrm{mM}$ Tris $/ \mathrm{HCl}(\mathrm{pH} \mathrm{7.5)}$ containing $3 \%(\mathrm{w} / \mathrm{v}) \mathrm{NaCl}$ at $75^{\circ} \mathrm{C}$ for $30 \mathrm{~min}$. After dehydration in a graded ethanol series, the specimen was immersed in $t$-butyl alcohol and dried using a freeze drying method, and finally sputter-coated with platinum under vacuum (E-1010 Ion sputter; Hitachi). The specimen was observed using a Hitachi S-800 scanning electron microscope at an accelerating voltage of $20 \mathrm{kV}$.

Analysis of lipid components. Respiratory lipoquinone, fatty acid and polar lipid analyses were carried out by Dr B. J. Tindall at the DSMZ, Braunschweig, Germany. Respiratory lipoquinones and polar lipids were extracted from $100 \mathrm{mg}$ of freeze-dried cell material using the two-stage method described by Tindall $(1990 \mathrm{a}, \mathrm{b})$. Respiratory quinones were extracted using methanol/hexane and the polar lipids were extracted by adjusting the remaining methanol $/ 0 \cdot 3 \%$ aqueous $\mathrm{NaCl}$ phase (containing the cell debris) to give a chloroform/methanol $/ 0.3 \%$ aqueous $\mathrm{NaCl}$ mixture $(1: 2: 0 \cdot 8$, by vol.). The extraction solvent was stirred overnight and the cell debris was pelleted by centrifugation. Polar lipids were recovered into the chloroform phase by adjusting the chloroform/methanol/0.3\% aqueous $\mathrm{NaCl}$ mixture to a ratio of $1: 1: 0.9$ (by vol.). Respiratory lipoquinones were separated into their different classes by TLC on silica gel (Macherey-Nagel), using hexane/tbutylmethylether $(9: 1, \mathrm{v} / \mathrm{v})$ as solvent. UV absorbing bands corresponding to menaquinones or ubiquinones were removed from the plate and further analysed by HPLC (LDC Analytical; Thermo Separation Products) fitted with a reverse phase column (Macherey-Nagel) using methanol as the eluant. Respiratory lipoquinones were detected at $269 \mathrm{~nm}$. Polar lipids were separated by two-dimensional silica gel TLC. The first direction was developed in chloroform/methanol/water (65:25:4, by vol.) and the second in chloroform/methanol/acetic acid/water $(80: 12: 15: 4$, by vol.). Total lipid material and specific functional groups were detected using dodecamolybdophosphoric acid (total lipids), Zinzadze reagent (phosphate), ninhydrin (free amino groups), periodate-Schiff ( $\alpha$-glycols), 
Dragendorff reagent (quaternary nitrogen) and anisaldehyde/sulphuric acid (glycolipids). Fatty acids were analysed as the methyl ester derivatives prepared from $10 \mathrm{mg}$ dry cell materials. Cells were subjected to differential hydrolysis to detect ester-linked and non-ester-linked (amide-bound) fatty acids. Fatty acid methyl esters were analysed by GC using a non-polar capillary column and flame ionization detection.

DNA base composition. Isolation of DNA was performed according to the method described by Visuvanathan et al. (1989). The DNA base composition was determined at the DSMZ by HPLC (Mesbah et al., 1989; Tamaoka \& Komagata 1984).

16S rDNA sequence analysis. DNA was extracted from overnight cultures following the method described by Charbonnier \& Forterre (Robb \& Place, 1995). The 16S rDNA gene was amplified by PCR using primers designed by DeLong (1992) and sequenced on an ABI 373S automated sequencer (Perkin Elmer/Applied Biosystems). The almost complete $16 \mathrm{~S}$ rDNA sequence of strain $\mathrm{KB}-1^{\mathrm{TP}}$, corresponding to positions 21-1526 (Escherichia coli numbering), was determined at the DSMZ and aligned with reference sequences by using the CLUSTAL W program, version 1.81 (Thompson et al., 1994). Pairwise evolutionary distances were computed by using the correction of Jukes \& Cantor (1969) and a distance matrix tree was constructed by the neighbour-joining method (Saitou \& Nei, 1987) employing the program PHYLIP (Felsenstein et al., 1993). The first and the last 80 bases were excluded from the phylogenetic analysis because of incomplete sequences reported for some strains and due to alignment uncertainties. A total of $1517 \mathrm{nt}$ (corresponding to positions 101-1452, E. coli numbering) were used in the analysis and the phylogenetic trees were displayed using version 1.6 of the TREEVIEW program of Page (1996). The root position of the tree was estimated using the 16S rRNA sequence of Caldicellulosiruptor saccharolyticus (DSM 8903 ${ }^{\mathrm{T}}$ ) as outgroup.

Nucleotide sequence accession numbers. Accession numbers for the sequences used as references are as follows: Thermoanaerobacter brockii subsp. brockii DSM 1457 ${ }^{\mathrm{T}}$, L09165; Thermoanaerobacter brockii subsp. finnii DSM $3389^{\mathrm{T}}$, L09166; Thermoanaerobacter brockii subsp. lactiethylicus DSM 9801 ${ }^{\mathrm{T}}$, U14330; Thermoanaerobacter mathranii $\mathrm{A}^{\mathrm{T}}$ (= DSM 11426 ${ }^{\mathrm{T}}$ ), Y11279; Thermoanaerobacter italicus Ab9 $^{\mathrm{T}} \quad\left(=\mathrm{DSM} 9252^{\mathrm{T}}\right)$, AJ250846; Thermoanaerobacter wiegelii Rt8.B1 ${ }^{\mathrm{T}}$ (= DSM 10319 $)$, X92513; Thermoanaerobacter acetoethylicus DSM 2359 ${ }^{\mathrm{T}}$, L09163; Thermoanaerobacter ethanolicus 39E (= DSM 2355), L09164; Thermoanaerobacter thermocopriae JT-3 ${ }^{\mathrm{T}}\left(=\mathrm{IAM} 13577^{\mathrm{T}}\right)$, L09167; Thermoanaerobacter sulfurophilus L-64 ${ }^{\mathrm{T}}$ (= DSM 11584 ${ }^{\mathrm{T}}$ ), Y16940; Thermoanaerobacter thermohydrosulfuricus DSM 567 ${ }^{\mathrm{T}}$, L09161; Thermoanaerobacter kivui DSM 2030 ${ }^{\mathrm{T}}$, L09160; Thermoanaerobacter siderophilus SR4 ${ }^{\mathrm{T}}$ (= DSM 12299 ${ }^{\mathrm{T}}$ ), AF120479; Moorella thermoautotrophica DSM 1974 ${ }^{\mathrm{T}}$, X77849; Moorella thermoacetica DSM 12797, AJ242494; Thermoanaerobacterium saccharolyticum DSM $7060^{\mathrm{T}}$, L09169; Thermoanaerobacterium thermosaccharolyticum D120-70, AF247003; Caldicellulosiruptor saccharolyticus DSM 8903 ${ }^{\mathrm{T}}$, AF130258.

\section{RESULTS}

\section{Enrichment and isolation}

Six samples from hot streams at Sileri in the Dieng volcanic area on the island of Java, Indonesia, were used for the enrichment of extremely thermophilic micro-organisms. To mimic the in situ temperatures and $\mathrm{pH}$ profile, enrichment cultures on EM-KB1 medium containing various carbon sources $\left(5 \cdot 0 \mathrm{~g} \mathrm{l}^{-1}\right)$ were incubated at temperatures between 70 and $100{ }^{\circ} \mathrm{C}$ and $\mathrm{pH} 4 \cdot 0-7 \cdot 0$. Primary enrichment cultures were prepared by adding $5.0 \mathrm{ml}$ sample water to $50 \mathrm{ml}$ EMKB1 medium under a $\mathrm{N}_{2}$ gas atmosphere. After 2 or $3 \mathrm{~d}$ of incubation at $80^{\circ} \mathrm{C}$, growth of rod-shaped micro-organisms was observed. Positive enrichment cultures were repeatedly transferred to fresh EM-KB1 medium supplemented with xylose $\left(5 \cdot 0 \mathrm{~g} \mathrm{l}^{-1}\right)$ and yeast extract $\left(0 \cdot 2 \mathrm{~g} \mathrm{l}^{-1}\right)$ and incubated at $80^{\circ} \mathrm{C}$ for $24 \mathrm{~h}$. Pure cultures were successfully obtained by the dilution-toextinction technique. Each of the diluted cultures was incubated for $3 \mathrm{~d}$ at $80^{\circ} \mathrm{C}$ and the serial dilutions $(1: 10)$ were repeated at least 10 times. The culture showing growth on xylose at the highest dilution was designated strain $\mathrm{KB}-1^{\mathrm{TP}}$ and was chosen for further investigation. Purity of the strain was confirmed by microscopic examinations and formation of homogeneous colonies on agar-solidified EM-KB1 medium in Hungate tubes. Liquid cultures of strain $\mathrm{KB}-1^{\mathrm{TP}}$ could be used as inoculum for at least 12 months when stored at $4{ }^{\circ} \mathrm{C}$.

\section{Colony and cell morphology}

Colonies of isolate KB-1 $1^{\mathrm{TP}}$ formed on solid EM-KB1 medium after $48 \mathrm{~h}$ of incubation at $70{ }^{\circ} \mathrm{C}$ appeared uniformly round, non-pigmented and flat with a diameter of 1-2 mm. Straight, rod-shaped single cells were observed in the phase-contrast microscope after growth in liquid culture incubated at 70 and $80^{\circ} \mathrm{C}$ for $12 \mathrm{~h}$ (in mid- to late exponential growth phase). Vegetative cells measured 0.4-0.8 $\times 1.0-3.0 \mu \mathrm{m}$ (Fig. $1 \mathrm{a}, \mathrm{b})$. When incubated at lower temperatures $\left(60^{\circ} \mathrm{C}\right.$ for $12 \mathrm{~h}$ ) cells of strain KB-1 ${ }^{\mathrm{TP}}$ were significantly longer (about $4 \cdot 0-5 \cdot 0 \mu \mathrm{m}$ ) than those incubated at 70 or $80{ }^{\circ} \mathrm{C}$ (Fig. 1c). An electron micrograph of an ultrathin section of strain KB-1 $1^{\mathrm{TP}}$ is shown in Fig. 2a. Observation at higher magnification revealed a twolayer structure of the cell wall (Fig. 2b), resembling those of Thermoanaerobacter ethanolicus JW200 ${ }^{\mathrm{T}}$ (Wiegel \& Ljungdahl, 1981) and Thermoanaerobacter wiegelii $\mathrm{Rt8} . \mathrm{B} 1^{\mathrm{T}}$ (Cook et al., 1996). Sporulating cells could be observed when the new isolate was incubated under suboptimal conditions, such as overnight at $85^{\circ} \mathrm{C}\left(\geqslant 10 \%\right.$ inoculum, v/v). Strain KB- $1^{\mathrm{TP}}$ formed a spherical, refractile endospore in terminally swollen sporangia. Phase-bright sulfur accumulated in the medium and on the cells. The Gram reaction was positive.

\section{Physiological characterization of growth}

The newly isolated bacterium grew strictly anaerobically under $\mathrm{N}_{2}$ or $\mathrm{N}_{2} / \mathrm{CO}_{2}(80: 20, \mathrm{v} / \mathrm{v})$ using $\mathrm{Na}_{2} \mathrm{~S}$ as a reducing agent. In oxidized medium, as indicated by the pink colour of the redox indicator resazurin, no growth occurred. Isolate $\mathrm{KB}-\mathrm{1}^{\mathrm{TP}}$ grew over a tem- 

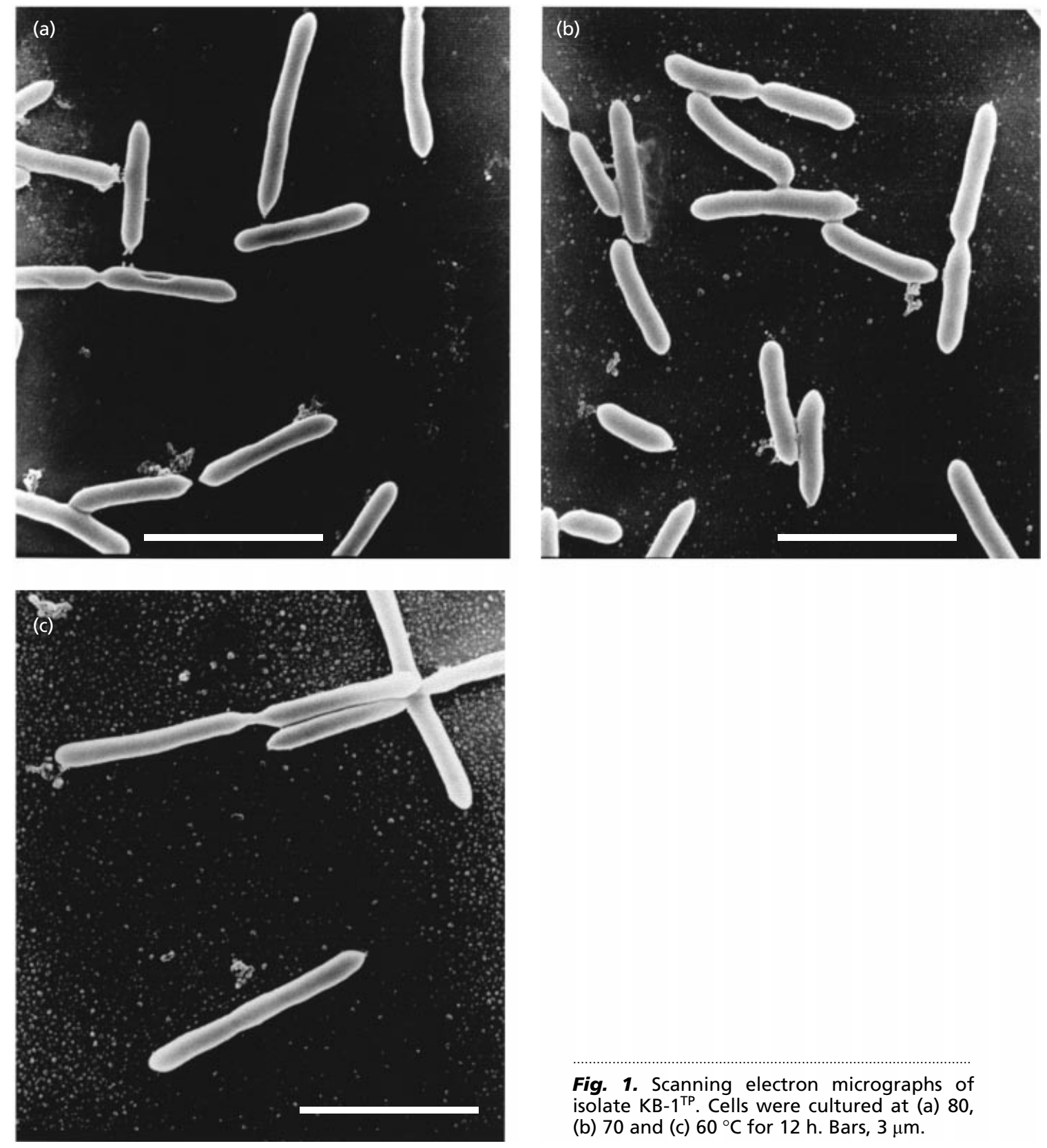

Fig. 1. Scanning electron micrographs of isolate $\mathrm{KB}-1^{\mathrm{TP}}$. Cells were cultured at (a) 80 , (b) 70 and (c) $60^{\circ} \mathrm{C}$ for $12 \mathrm{~h}$. Bars, $3 \mu \mathrm{m}$.

perature range of about $50-85^{\circ} \mathrm{C}$, showing optimal growth at $75^{\circ} \mathrm{C}$ (Fig. 3a). No growth was observed at 45 and $86^{\circ} \mathrm{C}$ even after prolonged incubation times ( $>1$ week). Growth of the new isolate at $75^{\circ} \mathrm{C}$ occurred between $\mathrm{pH} 4.5$ and 9.0 , with an optimum at pH 6.5 (Fig. 3b). No growth was observed at $\mathrm{pH} 4.0$ or below and $\mathrm{pH} 9.5$ or above. Under optimal cultivation conditions $\left(5.0 \mathrm{~g}\right.$ soluble starch $1^{-1}, 1.0 \mathrm{~g}$ yeast extract $1^{-1}, 2 \cdot 0 \mathrm{~g}$ thiosulfate $1^{-1}$ ) the generation time for the isolate was $60 \mathrm{~min}$. The maximum cell density was $5 \cdot 5 \times 10^{8}$ cells $\mathrm{ml}^{-1}$. Strain KB-1 ${ }^{\mathrm{TP}}$ grew well in GM$\mathrm{KB} 1$ medium without the addition of $\mathrm{NaCl}$ (final cell yield $5 \times 10^{8}$ cells $\mathrm{ml}^{-1}$ ). Growth was observed at $\mathrm{NaCl}$ concentrations up to $40 \mathrm{~g} \mathrm{l}^{-1}$ and no growth was observed at an $\mathrm{NaCl}$ concentration of $50 \mathrm{~g}^{-1}$. Growth was inhibited by the addition of $100 \mu \mathrm{g} \mathrm{ml}^{-1}$ each of tetracycline, chloramphenicol, penicillin $\mathrm{G}$, neomycin, kanamycin, vancomycin or rifampicin. At concentrations of $10 \mu \mathrm{g} \mathrm{ml}^{-1}$, however, the isolate grew in the presence of chloramphenicol and neomycin. These results indicate that strain $\mathrm{KB}-1^{\mathrm{TP}}$ belongs to the bacterial domain (Böck \& Kandler, 1985). In GM$\mathrm{KB} 1$ medium containing sodium thiosulfate $\left(2 \mathrm{~g} \mathrm{l}^{-1}\right)$, the final cell concentrations of the strains were as follows: Thermoanaerobacter brockii subsp. brockii

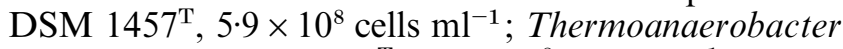
ethanolicus DSM $2246^{\mathrm{T}}, 2 \cdot 1 \times 10^{8}$ cells $\mathrm{ml}^{-1}$; strain $\mathrm{KB}-1^{\mathrm{TP}}, 5 \cdot 5 \times 10^{8}$ cells $\mathrm{ml}^{-1}$. However, in thiosulfatefree GM-KB1 medium, the final cell concentrations were: Thermoanaerobacter brockii subsp. brockii, 

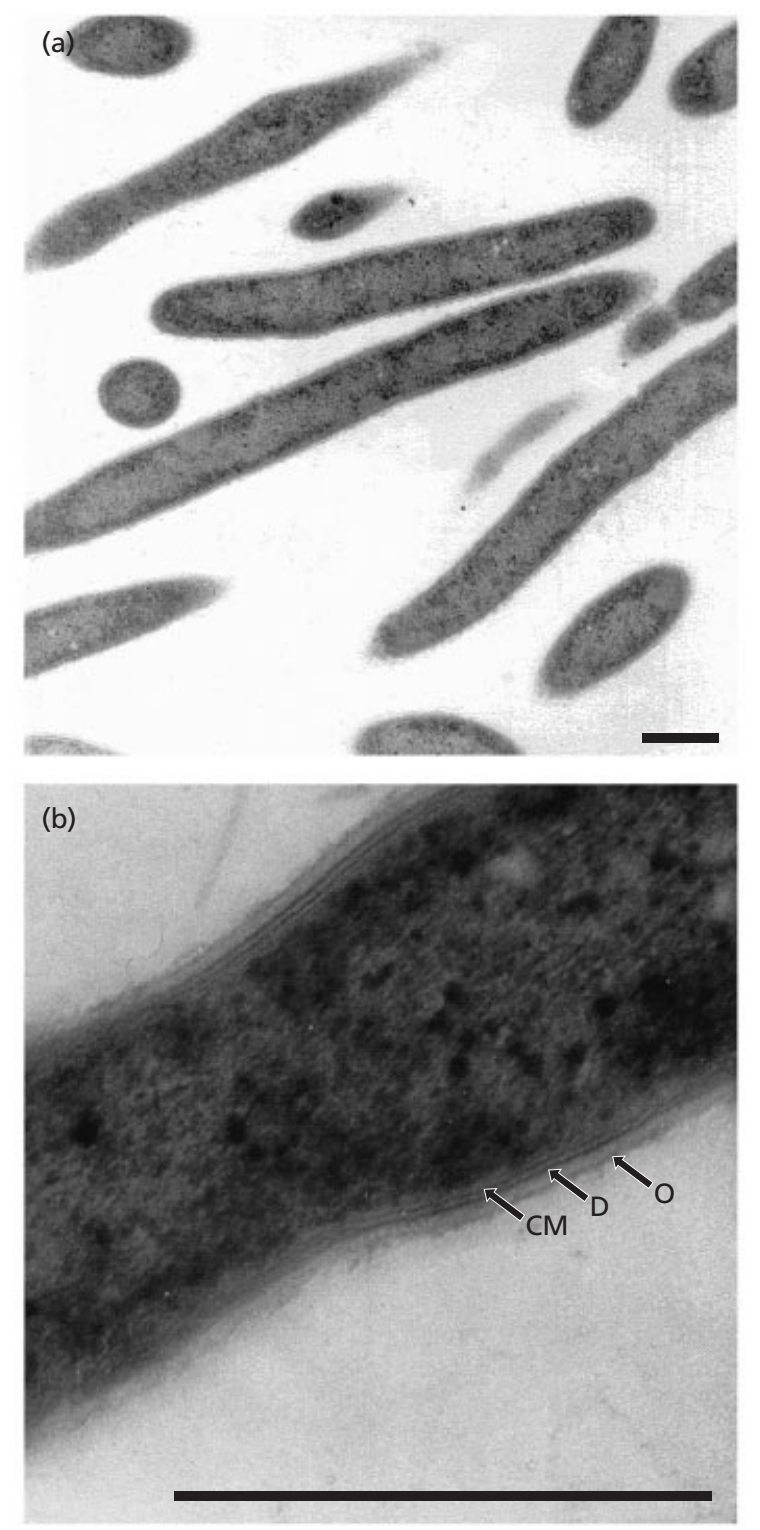

Fig. 2. Ultrastructure of isolate $\mathrm{KB}-1^{\mathrm{TP}}$. (a) Transmission electron micrograph. (b) Cell wall structure and cell membrane shown in detail. O, Outer cell wall; D, dense layer; CM, cytoplasmic membrane. Bars, $500 \mathrm{~nm}$.

$3.0 \times 10^{8}$ cells $\mathrm{ml}^{-1}$; Thermoanaerobacter ethanolicus, $4.5 \times 10^{7}$ cells ml ${ }^{-1}$; strain KB-1 ${ }^{\mathrm{TP}}, 2 \cdot 5 \times 10^{7}$ cells ml ${ }^{-1}$. In contrast to Thermoanaerobacter brockii and Thermoanaerobacter ethanolicus, the growth of strain $\mathrm{KB}-1^{\mathrm{TP}}$ was significantly lower without thiosulfate.

\section{Nutritional requirements and fermentation products}

Isolate $\mathrm{KB}-\mathrm{1}^{\mathrm{TP}}$ is a chemo-organotrophic bacterium able to utilize a wide variety of sugars, polysaccharides and proteins. Glucose, fructose, D-xylose, D-galactose, lactose, maltose, mannose, D-cellobiose, sucrose, soluble starch, pullulan, yeast extract, tryptone and peptone were fermented. No growth, however, was

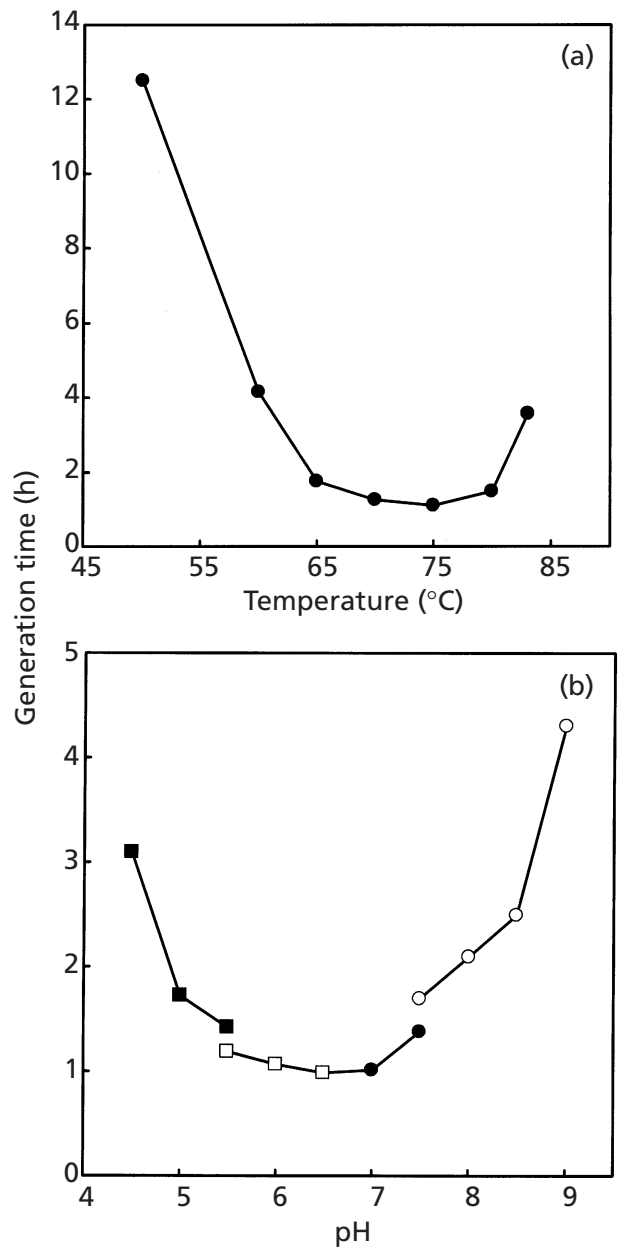

Fig. 3. (a) Effect of temperature on growth of strain $K B-1^{T P}$. (b) Effect of $\mathrm{pH}$ on growth of strain KB-1 ${ }^{\mathrm{TP}}$. Trisodium citrate buffer; $\square$, MES buffer; $\bigcirc$, Tris buffer; $\bigcirc$, sodium carbonate buffer. The $\mathrm{pH}$ values were the initial values adjusted at room temperature.

detected when arabinose, D-sorbitol, xylan, carboxymethylcellulose, olive oil, Tween 80, collagen and gelatin were used as carbon and energy source. Growth of strain KB-1 ${ }^{\mathrm{TP}}$ was dependent on yeast extract with a concentration of at least $0 \cdot 1 \mathrm{~g}^{-1}$. Sodium thiosulfate, sulfur, L-cystine and sodium nitrate served as final electron acceptors and only poor growth occurred if none of these electron acceptors were present in

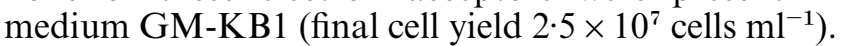
The newly isolated micro-organism reduced thiosulfate to sulfur and $\mathrm{H}_{2} \mathrm{~S}$. Sulfur was formed in the early phase of fermentation as indicated by phasebright sulfur aggregates in the light microscope (data not shown). In the late exponential growth phase GMKB1 medium turned black after the addition of a $\mathrm{FeSO}_{4}$ solution $\left(2 \cdot 0 \mathrm{~g} \mathrm{l}^{-1}\right)$, which precipitated as $\mathrm{FeS}$, indicating the presence of $\mathrm{H}_{2} \mathrm{~S}$. The major fermentation products after $15 \mathrm{~h}$ of growth on medium GMKB1 supplemented with glucose $\left(5 \cdot 0 \mathrm{~g} \mathrm{l}^{-1}\right)$ were lactate, acetic acid, ethanol, $\mathrm{CO}_{2}$ and $\mathrm{H}_{2} \mathrm{~S}$. Propionic 
Table 1. Characteristics of strain $\mathrm{KB}-1^{\mathrm{TP}}$ in comparison with other species of the genus Thermoanaerobacter

1, Thermoanaerobacter brockii subsp. brockii DSM 1457 (Cayol et al., 1995); 2, Thermoanaerobacter brockii subsp. finnii DSM $3389^{\mathrm{T}}$ (Cayol et al., 1995); 3, Thermoanaerobacter brockii subsp. lactiethylicus DSM 9801 ${ }^{\mathrm{T}}$ (Cayol et al., 1995); 4,

Thermoanaerobacter mathranii DSM $11426^{\mathrm{T}}$ (Larsen et al., 1997); 5, Thermoanaerobacter italicus DSM 9252 ${ }^{\mathrm{T}}$ (Kozianowski et al., 1997); 6, Thermoanaerobacter wiegelii DSM $10319^{\mathrm{T}}$ (Cook et al., 1996); 7, Thermoanaerobacter acetoethylicus DSM 2359 ${ }^{\mathrm{T}}$ (BenBassat \& Zeikus, 1981; Cayol et al., 1995); 8, Thermoanaerobacter ethanolicus DSM 2246 ${ }^{\mathrm{T}}$ (Wiegel \& Ljungdahl, 1981); 9, Thermoanaerobacter thermocopriae IAM $13577^{\mathrm{T}}$ (Jin et al., 1988); 10, Thermoanaerobacter sulfurophilus DSM $11584^{\mathrm{T}}$ (BonchOsmolovskaya et al., 1997); 11, Thermoanaerobacter thermohydrosulfuricus DSM 567 (Lee et al., 1993); 12, Thermoanaerobacter kivui DSM 2030 (Leigh et al., 1981); 13, Thermoanaerobacter siderophilus DSM 12299 (Slobodkin et al., 1999); 14, Strain KB$1^{\mathrm{TP}}$ (data from this study). +, Positive; - , negative; v, variable; ND, no data available.

\begin{tabular}{|c|c|c|c|c|c|c|c|c|c|c|c|c|c|c|}
\hline Characteristic & 1 & 2 & 3 & 4 & 5 & 6 & 7 & 8 & 9 & 10 & 11 & 12 & 13 & 14 \\
\hline $16 \mathrm{~S}$ rDNA similarity to strain $\mathrm{KB}-1^{\mathrm{TP}}(\%)$ & $92 \cdot 7$ & $92 \cdot 7$ & $91 \cdot 9$ & $91 \cdot 4$ & $91 \cdot 8$ & $92 \cdot 2$ & $90 \cdot 6$ & $90 \cdot 7$ & $91 \cdot 4$ & $92 \cdot 0$ & $91 \cdot 8$ & $92 \cdot 2$ & $91 \cdot 1$ & 100 \\
\hline $\mathrm{G}+\mathrm{C}$ content $(\mathrm{mol} \%)$ & $30-31$ & 32 & 35 & 37 & $34-35$ & $35-36$ & 31 & 32 & $37-38$ & $30-31$ & $29-32$ & 38 & 32 & 37 \\
\hline \multicolumn{15}{|l|}{ Growth temperature $\left({ }^{\circ} \mathrm{C}\right)$} \\
\hline Maximum & $<85$ & 75 & 75 & $<78$ & 78 & 78 & 80 & 78 & 74 & 75 & 78 & 75 & 78 & 85 \\
\hline Optimum & $65-75$ & 65 & $55-60$ & $70-75$ & 70 & $65-68$ & 65 & 69 & 60 & $55-60$ & $67-69$ & 66 & $69-71$ & 75 \\
\hline Spore formation & + & + & + & + & + & + & - & - & + & - & + & - & + & + \\
\hline Gram staining & + & v & + & $\mathrm{v}$ & - & - & - & $\mathrm{v}$ & - & + & v & - & ND & + \\
\hline \multicolumn{15}{|l|}{ Utilization of: } \\
\hline Starch & + & ND & $\mathrm{ND}$ & + & + & + & + & + & + & + & + & - & + & + \\
\hline Xylan & ND & ND & ND & + & + & ND & - & + & ND & + & + & ND & - & - \\
\hline Xylose & - & + & + & + & + & + & - & + & + & + & + & ND & + & + \\
\hline
\end{tabular}

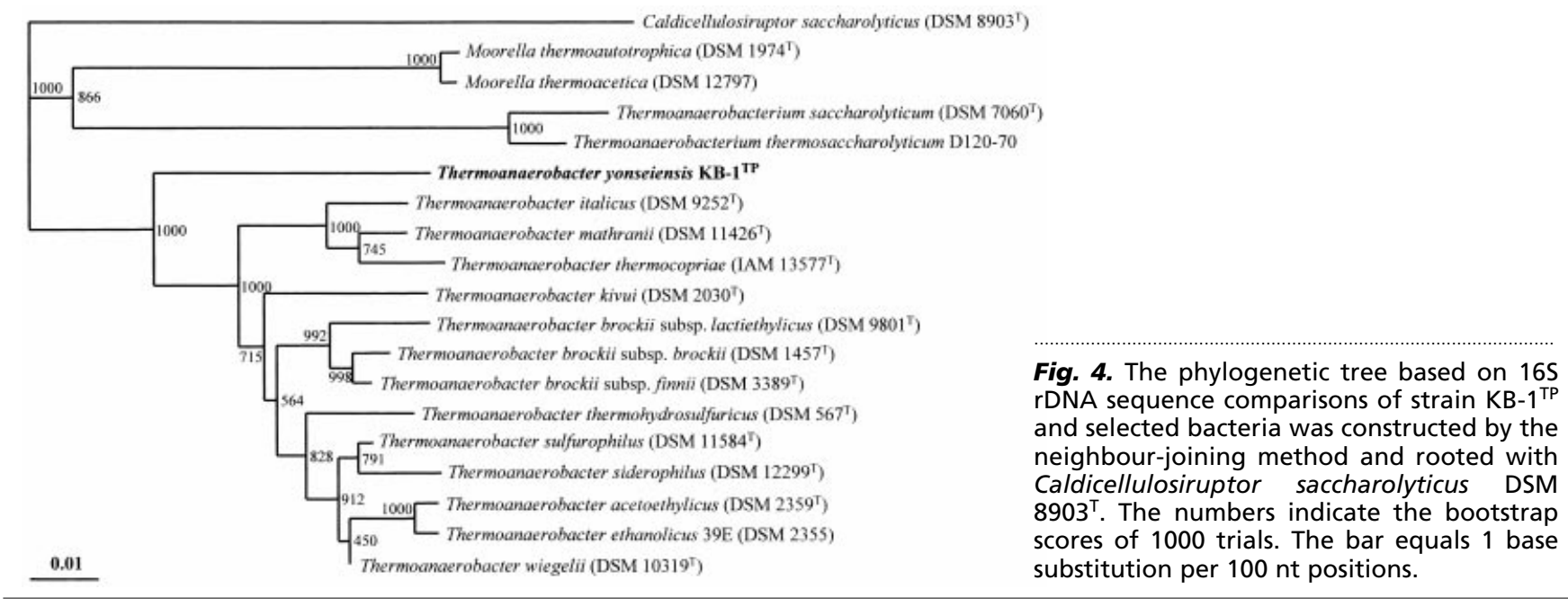

acid, butyric acid, isovaleric acid, 2-propanol and 1pentanol could be detected in low concentrations $(<0 \cdot 2 \mathrm{mM})$.

\section{Analysis of lipid components}

As shown by TLC, strain KB-1 ${ }^{\mathrm{TP}}$ possesses glycolipids. Due to the weak staining of the glycolipids, they did not appear to be identical to known glycolipids that contain glucose, mannose or galactose. Some of these unusual glycolipids could not be assigned to any known structure since they did not stain for phosphate or amino groups, nor did they show a strong reaction with the reagents used for sugar detection. Respiratory lipoquinones, such as menaquinones and ubiquinones, were not found. The major cellular fatty acids of the new isolate grown on medium GM-KB1 at $75^{\circ} \mathrm{C}$ were: iso- $\mathrm{C}_{15: 0}(42 \%)$, iso- $\mathrm{C}_{17: 0}(11 \%), \mathrm{C}_{16: 0}(7 \%)$,
$\mathrm{C}_{18: 1} \omega 7 c(6 \%), 3-\mathrm{OH}$ iso- $\mathrm{C}_{14: 0}(6 \%)$, anteiso- $\mathrm{C}_{15: 0}$ $(5 \%)$ and anteiso- $\mathrm{C}_{17: 0}(5 \%)$.

\section{Phylogenetic analysis}

The almost complete sequence (1501 bp) of the $16 \mathrm{~S}$ rRNA gene from strain KB-1 $1^{\mathrm{TP}}$ was determined and aligned with available sequences of members of the Bacillus/Clostridium subphylum of the Gram-positive bacteria. Based on the sequence analysis, the $16 \mathrm{~S}$ rDNA sequence had less than $92.7 \%$ similarity with any other known sequences. The most similar rDNA sequences were those of Thermoanaerobacter brockii subsp. brockii, Thermoanaerobacter brockii subsp. finnii and Thermoanaerobacter brockii subsp. lactiethylicus with 91.9-92.7\% similarity (Table 1). Pairwise evolutionary distances were computed as described in Methods and employed in the construc- 
tion of a phylogenetic dendrogram. The phylogenetic position of isolate $\mathrm{KB}-1^{\mathrm{TP}}$ within the radiation of cluster V of the clostridia (Collins et al., 1994) is shown in Fig. 4. The $\mathrm{G}+\mathrm{C}$ content was $37 \mathrm{~mol} \%$ and the $\mathrm{G}+\mathrm{C}$ content of the $16 \mathrm{~S}$ rDNA was $59 \cdot 6 \mathrm{~mol} \%$.

\section{DISCUSSION}

According to current classification rules, the new isolate, strain $\mathrm{KB}-1^{\mathrm{TP}}$, can be considered to be a species of the genus Thermoanaerobacter. This assumption is supported by the examination of the almost complete 16S rDNA sequence, which clearly places strain $\mathrm{KB}-1^{\mathrm{TP}}$ in cluster $\mathrm{V}$ of the clostridia as described by Collins et al. (1994). In addition, morphological and physiological characteristics of strain $\mathrm{KB}-1^{\mathrm{TP}}$, such as $\mathrm{H}_{2} \mathrm{~S}$ production from thiosulfate, spore formation and sensitivity to antibiotics, are in agreement with those of other described Thermoanaerobacter species.

Bacteria belonging to the genus Thermoanaerobacter are all thermophilic, anaerobic, rod-shaped bacteria that grow optimally in a temperature range between 60 and $70^{\circ} \mathrm{C}$. Strain KB-1 $1^{\mathrm{TP}}$ displays a temperature optimum of $75^{\circ} \mathrm{C}$ and a maximum growth temperature of $85^{\circ} \mathrm{C}$, which is significantly higher than that of any other Thermoanaerobacter species. Among Thermoanaerobacter species, only two species are reported to grow at $80^{\circ} \mathrm{C}$, namely Thermoanaerobacter acetoethylicus and Thermoanaerobacter brockii subsp. brockii (Cayol et al., 1995). However, these species do not utilize xylose as sole carbon source (Cayol et al., 1995). Interestingly, unlike Thermoanaerobacter acetoethylicus and Thermoanaerobacter brockii subsp. brockii, the newly isolated strain utilizes D-xylose as sole carbon source (Table 1) and produces a thermostable D-xylose isomerase (data not shown). When grown on glucose and in the presence of thiosulfate the newly isolated micro-organism forms fermentation products which are typical for members of the genus Thermoanaerobacter. But in contrast to other validly described Thermoanaerobacter species, strain $\mathrm{KB}-1^{\mathrm{TP}}$ additionally produces propionate and 1pentanol from glucose. The fact that lactate was found to be the major fermentation product on glucose/ thiosulfate is an uncommon finding among Thermoanaerobacter species, since members of this genus mostly form ethanol or acetate as major fermentation products. Growth of strain KB- $1^{\mathrm{TP}}$ is dependent on the presence of yeast extract which is - except in the case of Thermoanaerobacter wiegelii - a common growth factor for Thermoanaerobacter species (Cook et al., 1996). Thiosulfate reduction to sulfide is a common trait of sulfate-reducing bacteria such as Thermoanaerobacterium and Thermoanaerobacter (Lee et al., 1993a). This feature is also observed for the order Thermotogales (Ravot et al., 1995). In the case of the genus Thermoanaerobacter, a faster growth rate and increased cell yield were obtained in the presence of thiosulfate than in its absence (Fardeau et al., 1996). However, the dependency of thiosulfate as an electron acceptor is different among Thermoanaerobacter species. Unlike Thermoanaerobacter brockii subsp. brockii DSM $1457^{\mathrm{T}}$ and Thermoanaerobacter ethanolicus DSM $2246^{\mathrm{T}}$, strain $\mathrm{KB}-1^{\mathrm{TP}}$ requires either thiosulfate or sulfur as final electron acceptor and only poor growth was observed when these compounds were not added to the medium. These results suggest that the requirement of electron acceptor for growth is one of the important distinguishing physiologies among Thermoanaerobacter species and further analyses for the other Thermoanaerobacter species is needed. Analysis of cellular lipids revealed the presence of uncommon glycolipids that could not be assigned to any known bacterial glycolipids. Although the cellular lipid composition is regarded as an important taxonomic factor (Asselineau \& Asselineau, 1990; Jenkins, 1981), information in this particular field is not available for other Thermoanaerobacter species. Therefore, it is impossible to compare the results of lipid analysis of strain KB-1 ${ }^{\mathrm{TP}}$ with those of other members of the genus Thermoanaerobacter. However, this report on the cellular lipids and respiratory quinones in the genus Thermoanaerobacter may encourage other researchers to conduct similar studies of this indicative taxonomic feature.

Beside the physiological differences mentioned above, the new isolate is phylogenetically distant from members of the Bacillus/Clostridium subphylum as shown by $16 \mathrm{~S}$ rDNA sequence analysis. The $16 \mathrm{~S}$ rDNA sequence of strain KB-1 ${ }^{\mathrm{TP}}$ showed the highest similarity of $92.7 \%$ to those of Thermoanaerobacter brockii subsp. brockii and subsp. finnii. This value is very low and would even justify its classification to a new genus based on the phylogenetic dendrogram (Fig. 4). Strain KB-1 ${ }^{\mathrm{TP}}$ forms no subcluster with any species of the genus Thermoanaerobacter and shows a rather isolated position that branches off very early. This branch received $100 \%$ bootstrap support. However, taking into account the morphological and physiological characteristics, strain $\mathrm{KB}-1^{\mathrm{TP}}$ can be easily accommodated in the genus Thermoanaerobacter rather than a new taxonomical group.

\section{Description of Thermoanaerobacter yonseiensis sp. nov.}

Thermoanaerobacter yonseiensis (yon.sei.en'sis. N.L. adj. yonseiensis pertaining to Yonsei University, Seoul, Korea, in recognition of its support of research on extreme thermophiles and their thermostable enzymes).

Cells are Gram-positive, straight, rod-shaped and motile. Size of vegetative cells in exponential growth phase is $0.4-0.8 \times 1.0-3.0 \mu \mathrm{m}$. Under suboptimal conditions cells occur in long chains and terminal spores are observed. Optimal conditions for growth are $75^{\circ} \mathrm{C}$ (range $50-85^{\circ} \mathrm{C}$ ) and $\mathrm{pH} 6.5$ (range 4.5-9.0). The doubling time under optimal conditions on medium containing starch/yeast extract/thiosulfate is 60 min. Cells grow chemo-organotrophically under 
strict anaerobic conditions on glucose, fructose, lactose, maltose, D-xylose, D-galactose, mannose, sucrose, cellobiose, starch, pullulan, yeast extract, tryptone and peptone. L-Arabinose, D-sorbitol, xylan, carboxymethylcellulose, olive oil, Tween 80, collagen and gelatin are not utilized. Cells require yeast extract, elemental sulfur, L-cystine, sodium nitrate or sodium thiosulfate for growth. Major fermentation products on glucose are lactate, acetate, ethanol, $\mathrm{CO}_{2}$ and $\mathrm{H}_{2} \mathrm{~S}$. Propionate, butyrate, isovalerate, 2-propanol and 1pentanol are formed in small amounts. Growth on glucose is inhibited by tetracycline, chloramphenicol, penicillin $G$, neomycin, vancomycin, kanamycin and rifampicin $\left(100 \mu \mathrm{g} \mathrm{ml}^{-1}\right)$. Growth was observed at $\mathrm{NaCl}$ concentrations up to $40 \mathrm{~g}^{-1}$. Respiratory lipoquinones are absent. Major cellular fatty acids are iso- $\mathrm{C}_{15: 0}$, iso- $\mathrm{C}_{17: 0}, \mathrm{C}_{16: 0}, \mathrm{C}_{18: 1} \omega 7 c, 3-\mathrm{OH}$ iso- $\mathrm{C}_{14: 0}$, anteiso- $\mathrm{C}_{15: 0}$ and anteiso- $\mathrm{C}_{17: 0}$. $\mathrm{G}+\mathrm{C}$ content of the DNA is $37 \mathrm{~mol} \%$. Type strain $\mathrm{KB}-1^{\mathrm{TP}}$ was isolated from mud samples taken from a hot stream at Sileri in the Dieng volcanic area located on the island of Java, Indonesia, and has been deposited in the Korean Federation of Culture Collections (KFCC $11116^{\mathrm{P}}$ ) as a patent strain and deposited in the Deutsche Sammlung von Mikroorganismen und Zellkulturen as a type strain $\left(=\right.$ DSM $\left.13777^{\mathrm{T}}\right)$.

\section{ACKNOWLEDGEMENTS}

This work was supported by the Korea Science and Engineering Foundation (KOSEF) through the Bioproducts Research Center at Yonsei University (2000-2-0173). We thank Dr B. J. Tindall at the DSMZ for the respiratory lipoquinone, fatty acid and polar lipid analyses, and Professor H. G. Trüper for valuable advice in nomenclature.

\section{REFERENCES}

Asselineau, C. \& Asselineau, J. (1990). Lipid analysis in bacterial taxonomy: proposal for a standardized method. Biochem Cell Biol 68, 379-386.

Balch, W. E., Fox, G. E., Magrum, L. J., Woese, C. R. \& Wolfe, R. S. (1979). Methanogens: re-evaluation of a unique biological group. Microbiol Rev 43, 260-296.

Ben-Bassat, A. \& Zeikus, J. G. (1981). Thermobacteroides acetoethylicus gen. nov. sp. nov., a new chemoorganotrophic, anaerobic, thermophilic bacterium. Arch Microbiol 128, 365-370.

Bonch-Osmolovskaya, E. A., Miroshnichenko, M. L., Chernyh, N. A., Kostrikina, N. A., Pikuta, E. V. \& Rainey, F. A. (1997). Reduction of elemental sulfur by moderately thermophilic organotrophic bacteria and the description of Thermoanaerobacter sulfurophilus sp. nov. Microbiology (English translation of Mikrobiologiya) 66, 483-489.

Böck, A. \& Kandler, O. (1985). Antibiotic sensitivity of archaebacteria. In The Bacteria, vol. 8, pp. 525-544. Edited by J. R. Sokatch, L. N. Ornston \& C. R. Woese. Orlando: Academic Press.

Brock, T. D. \& Madigan, M. T. (1988). Biology of Microorganisms, 5th edn. Englewood Cliffs, NJ : Prentice-Hall.

Brown, S. H., Sjøholm, C. \& Kelly, R. M. (1993). Purification and characterization of a highly thermostable glucose isomerase produced by the extremely thermophilic eubacterium, Thermotoga maritima. Biotechnol Bioeng 41, 878-886.

Cayol, J.-L., Ollivier, B., Patel, B. K. C., Ravot, G., Magot, G., Ageron, E., Grimont, P. A. D. \& Garcia, J.-L. (1995). Description of Thermoanaerobacter brockii subsp. lactiethylicus subsp. nov., isolated from a deep subsurface French oil well, a proposal to reclassify Thermoanaerobacter finnii as Thermoanaerobacter brockii subsp. finnii comb. nov., and an emended description of Thermoanaerobacter brockii. Int J Syst Bacteriol 45, 783-789.

Collins, M. D., Lawson, P. A., Willems, A., Cordoba, J. J., Fernandez-Garayzabal, J., Garcia, P., Cai, J., Hippe, H. \& Farrow, J. A. E. (1994). The phylogeny of the genus Clostridium: proposal of five new genera and eleven species combinations. Int J Syst Bacteriol 44, 812-826.

Cook, G. M., Janssen, P. H. \& Morgan, H. W. (1991). Endospore formation by Thermoanaerobium brockii HTD4. Syst Appl Microbiol 14, 240-244.

Cook, G. M., Rainey, F. A., Patel, B. K. \& Morgan, H. W. (1996). Characterization of a new obligately anaerobic thermophile, Thermoanaerobacter wiegelii. Int J Syst Bacteriol 6, 123-127.

Dekker, K., Yamataga, H., Sakaguchi, K. \& Udaka, S. (1991a). Xylose (glucose) isomerase gene from the thermophile Thermus thermophilus: cloning, sequencing, and comparison with other thermostable xylose isomerases. J Bacteriol 173, 3078-3083.

Dekker, K., Yamagata, H., Sakaguchi, K. \& Udaka, S. (1991b). Xylose (glucose) isomerase gene from the thermophile Clostridium thermohydrosulfuricum: cloning, sequencing, and expression in Escherichia coli. Agric Biol Chem 55, 221-227.

DeLong, E. F. (1992). Archaea in coastal marine environments. Proc Natl Acad Sci U S A 89, 5685-5689.

Erbeznik, M., Dawson, K. A. \& Strobel, H. J. (1998). Cloning and characterization of transcription of the $x y l A B$ operon in Thermoanaerobacter ethanolicus. J Bacteriol 180, 1103-1109.

Fardeau, M. L., Faudon, C., Cayol, J. L., Magot, M., Patel, B. K. C. \& Ollivier, B. (1996). Effect of thiosulphate as electron acceptor on glucose and xylose oxidation by Thermoanaerobacter finnii and a Thermoanaerobacter sp. isolated from oil field water. Res Microbiol 147, 159-165.

Fardeau, M.-L., Magot, M., Patel, B. K. C., Thomas, P., Garcia, J.-L. \& Ollivier, B. (2000). Thermoanaerobacter subterraneus sp. nov., a novel thermophile isolated from oilfield water. Int J Syst Evol Microbiol 50, 2141-2149.

Felsenstein, J. (1993). PHYLIP (Phylogeny Inference Package) version 3.5.1. Seattle: Department of Genetics, University of Washington.

Jander, G. \& Blasius, E. (1995). Lehrbuch der Analytischen und Präparativen Anorganischen Chemie, 14th edn. Stuttgart: Hirzel.

Jenkins, P. A. (1981). Lipid analysis for the identification of mycobacteria: an appraisal. Rev Infect Dis 3, 862-866.

Jin, F., Yamasato, K. \& Toda, K. (1988). Clostridium thermocopriae sp. nov., a cellulolytic thermophile from animal feces, compost, and a hot-spring in Japan. Int J Syst Bacteriol 38, 279-281.

Jukes, T. H. \& Cantor, C. R. (1969). Evolution of protein molecules. In Mammalian Protein Metabolism, pp. 21-132. Edited by H. N. Munro. New York: Academic Press.

Kozianowski, G., Canganelle, F., Rainey, F. A., Hippe, H. \& Antranikian, G. (1997). Purification and characterization of thermostable pectate-lyases from a newly isolated thermophilic bacterium, Thermoanaerobacter italicus sp. nov. Extremophiles 1, 171-182.

Larsen, L., Nielsen, P. \& Ahring, B. K. (1997). Thermoanaerobacter 
mathranii sp. nov., an ethanol-producing, extremely thermophilic anaerobic bacterium from a hot spring in Iceland. Arch Microbiol 168, 114-119.

Lee, Y.-E., Jain, M. K., Lee, C., Lowe, S. \& Zeikus, J. G. (1993a). Taxonomic distinction of saccharolytic thermophilic anaerobes: description of Thermoanaerobacterium xylanolyticum gen. nov., sp. nov., and Thermoanaerobacterium saccharolyticum gen. nov., sp. nov.; reclassification of Thermoanaerobium brockii, Clostridium thermosulfurogenes, and Clostridium thermohydrosulfuricum E100-69 as Thermoanaerobacter brockii comb. nov., Thermoanaerobacterium thermosulfurigenes comb. nov., and Thermoanaerobacter thermohydrosulfuricus comb. nov., respectively; and transfer of Clostridium thermohydrosulfuricum 39E to Thermoanaerobacter ethanolicus. Int J Syst Bacteriol 43, 41-51.

Lee, Y. E., Ramesh, M. V. \& Zeikus, J. G. (1993b). Cloning, sequencing and biochemical characterization of xylose isomerase from Thermoanaerobacterium saccharolyticum strain B6A-RI. J Gen Microbiol 139, 1227-1234.

Leigh, J. A., Mayer, F. \& Wolfe, R. S. (1981). Acetogenium kivui, a new thermophilic hydrogen oxidizing, acetogenic bacterium. Arch Microbiol 129, 275-280.

Liu, S. Y., Wiegel, J. \& Gherardini, F. C. (1996). Purification and cloning of a thermostable xylose (glucose) isomerase with acidic $\mathrm{pH}$ optimum from Thermoanaerobacterium strain JW/SLYS489. J Bacteriol 178, 5938-5945.

Meaden, P. G., Aduse-Opoku, J., Reizer, J., Reizer, A., Lanceman, Y. A., Martin, M. F. \& Mitchell, W. J. (1994). The xylose isomeraseencoding gene $(x y l A)$ of Clostridium thermosaccharolyticum: cloning, sequencing and phylogeny of XylA enzyme. Gene 141, 97-101.

Mesbah, M., Premachandran, U. \& Whitman, W. B. (1989). Precise measurement of the $\mathrm{G}+\mathrm{C}$ content of deoxyribonucleic acid by high-performance liquid chromatography. Int J Syst Bacteriol 39, 159-167.

Page, R. D. M. (1996). TREEVIEW: an application to display phylogenetic trees on personal computers. Comput Appl Biosci 12, 357-358.

Park, B. C., Koh, S., Chang, C., Suh, S. W., Lee, D. S. \& Byun, S. M. (1997). Cloning and expression of the gene for xylose isomerase from Thermus flavus AT62 in Escherichia coli. Appl Biochem Biotechnol 62, 15-27.

Rainey, F. A. \& Stackebrandt, E. (1993). Transfer of the type species of the genus Thermobacteroides to the genus Thermoanaerobacter as Thermoanaerobacter acetoethylicus (Ben-Bassat and Zeikus 1981) comb. nov., description of Coprothermobacter gen. nov., and reclassification of Thermobacteroides proteolyticus as Coprothermobacter proteolyticus (Ollivier et al. 1985) comb. nov. Int J Syst Bacteriol 43, 857-859.

Rainey, F. A., Ward, N. L., Morgan, H. W., Toalster, R. \& Stackebrandt, E. (1993). Phylogenetic analysis of anaerobic thermophilic bacteria: aid for their reclassification. J Bacteriol 175, 4772-4779.
Ravot, G., Ollivier, B., Magot, M., Patel, B. K. C., Crolet, J.-L., Fardeau, M.-L. \& Garcia, J.-L. (1995). Thiosulphate reduction: an important physiological feature shared by members of the Thermotogales. Appl Environ Microbiol 61, 2053-2055.

Robb, F. T. \& Place, A. R. (1995). Archaea, a laboratory manual: thermophiles. In Purification of Plasmids from Thermophilic and Hyperthermophilic Archaea, pp. 87-90. Edited by F. Charbonnier \& P. Forterre. Cold Spring Harbor, NY: Cold Spring Harbor Laboratory.

Saitou, N. \& Nei, M. (1987). The neighbor-joining method: a new method for reconstructing phylogenetic trees. Mol Biol Evol 4, 406-425.

Slobodkin, A. I., Tourova, T.P., Kuznetsov, B. B., Kostrikina, N. A., Chernyh, N. A. \& Bonch-Osmolovskaya, E. A. (1999). Thermoanaerobacter siderophilus sp. nov., a novel dissimilatory $\mathrm{Fe}(\mathrm{III})$-reducing, anaerobic, thermophilic bacterium. Int $J$ Syst Bacteriol 49, 1471-1478.

Stetter, K. O. (1996). Hyperthermophilic procaryotes. FEMS Microbiol Rev 18, 149-158.

Tamaoka, J. \& Komagata, K. (1984). Determination of DNA base composition by reversed-phase high-performance liquid chromatography. FEMS Microbiol Lett 25, 125-128.

Thompson, J. D., Higgins, D. G. \& Gibson, T. J. (1994). CLUSTAL $\mathrm{W}$ : improving the sensitivity of progressive multiple sequence alignment through sequence weighting, position specific gap penalties and weight matrix choice. Nucleic Acids Res 22, 4673-4680.

Tindall, B. J. (1990a). A comparative study of the lipid composition of Halobacterium saccharovorum from various sources. Syst Appl Microbiol 13, 128-130.

Tindall, B. J. (1990b). Lipid composition of Halobacterium lacusprofundi. FEMS Microbiol Lett 66, 199-202.

Vielle, C., Hess, J. M., Kelly, R. M. \& Zeikus, J. G. (1995). $x y l A$ cloning and sequencing, and biochemical characterization of xylose isomerase from Thermotoga neapolitana. Appl Environ Microbiol 61, 1867-1875.

Visuvanathan, S., Moss, M. T., Stanford, J. L., Hermon-Taylor, J. \& McFadden, J. J. (1989). Simple enzymatic method for isolation of DNA from diverse bacteria. J Microbiol Methods 10, 59-64.

Wiegel, J. \& Ljungdahl, L. G. (1981). Thermoanaerobacter ethanolicus gen. nov., sp. nov., a new extreme thermophilic, anaerobic bacterium. Arch Microbiol 128, 343-348.

Wiegel, J., Ljungdahl, L. G. \& Rawson, J. R. (1979). Isolation from soil and properties of the extreme thermophile Clostridium thermohydrosulfuricum. $J$ Bacteriol 139, 800-810.

Wolin, E. A., Wolfe, R. S. \& Wolin, M. J. (1964). Viologen dye inhibition of methane formation by Methanobacillus omelanskii. J Bacteriol 87, 993-998.

Zeikus, J. G., Hegge, P. W. \& Anderson, M. A. (1979). Thermoanaerobium brockii gen. nov. sp. nov., a new chemoorganotrophic, caldoactive, anaerobic bacterium. Arch Microbiol 122, 41-48. 